\title{
Galactose Metabolism in Human Ovarian Tissue
}

\author{
Y-K. XU, ${ }^{1}$ W. G. NG, F. R. KAUFMAN, R. A. LOBO, AND G. N. DONNELL \\ Department of Pediatrics [Y-K.X., W.G.N., F.R.K., G.N.D.], Children's Hospital of Los Angeles, Los Angeles, \\ California 90054, and Department of Obstetrics and Gynecology, University of Southern California School of \\ Medicine, Los Angeles County/University of Southern California Women's Hospital, Los Angeles, California \\ 90033
}

\begin{abstract}
Galactose metabolism was studied in human ovarian tissue obtained from 14 women controls between 21 and 72 y of age, and one 21-y-old galactosemic patient with hypergonadotrophic hypogonadism. Tissue slices were incubated with $1-{ }^{14} \mathrm{C}$-galactose, and labeled intermediates were analyzed by anion-exchange column chromatography. Activities of enzymes related to the galactose pathway: galactokinase, transferase, epimerase, uridine diphosphoglucose (UDPGIc) and uridine diphosphogalactose pyrophosphorylases, and UDPGIc and uridine diphosphogalactose pyrophosphatases were measured in ovarian homogenates using radioisotopic, spectrophotometric, and fluorometric techniques. Incorporation of carbon label from $1{ }^{14} \mathrm{C}$-galactose into various galactose and glycolytic intermediates, as well as carbon dioxide and TCA-insoluble materials was demonstrated in samples from non-galactosemic controls. In tissue from the galactosemic individual, no labeled carbon dioxide was produced and very little incorporation into TCA-insoluble material was found. Labeled galactose-1-phosphate was elevated. In normal ovarian tissue, specific activities of galactokinase, transferase, epimerase, and UDPGIc pyrophosphorylase are much higher than those found in the red cells and in testes. UDPGIc pyrophosphorylase activity is about 50 times that of transferase, suggesting that uridine nucleotide sugars have an important role in the normal development and function of the ovary. It is hypothesized that premature ovarian failure, often observed in patients with galactosemia, is due to interference with nucleotide sugar metabolism and the synthesis of galactose containing glycoproteins and glycolipids consequent to the enzymatic defect in the major pathway of galactose metabolism. (Pediatr Res 25:151-155, 1989)
\end{abstract}

\section{Abbreviations}

transferase, galactose-1-phosphate uridyl transferase epimerase, uridine diphosphogalactose-4-epimerase G6PD, glucose-6-phosphate dehydrogenase PGM, phosphoglucomutase

TCA, trichloroacetic acid

UDPGlc, uridine diphosphoglucose

UDPGal, uridine diphosphogalactose UTP, uridine triphosphate

Premature ovarian failure has been found with high frequency in female patients affected with galactosemia, even when dietary

Received April 19, 1988; accepted September 23, 1988.

Reprint requests W. G. Ng. Division of Medical Genetics, Children's Hospital of Los Angeles, P.O. Box 54700, Los Angeles, CA 90054.

Yan-Kang Xu is a research fellow in the Division of Medical Genetics, CHLA, from Sun-Yat Sen University of Medical Sciences. Guangzhou, China. treatment is begun in early infancy (1). The clinical symptoms of gonadal insufficiency have included partial or complete failure of secondary sexual development, primary amenorrhea, the postpubertal occurrence of oligomenorrhea, and secondary amenorrhea. Although streak ovaries have been observed in two patients $(2,3)$, the pathophysiology of the ovarian insult is unknown. It has been hypothesized that metabolites of galactose, particularly galactose-1-phosphate, may be toxic to the ovarian parenchyma during the prenatal state (4) or the perinatal period (1). The exact mechanism of this toxicity, however, has not been elucidated.

To gain a better understanding of galactose metabolism in the normal human ovary, galactose oxidation and its by-products were studied in ovarian tissue slices. In addition, the enzymes involved in the metabolic process were assayed, including galactokinase, galactose-1-phosphate uridyl transferase, UDPGal-4epimerase, UDPGal and UDPGlc pyrophosphorylases, and UDPGal and UDPGlc pyrophosphatases. Preliminary results in part have been presented (5).

\section{MATERIALS AND METHODS}

$1-{ }^{14} \mathrm{C}$-D-galactose $(15 \mathrm{mCi} / \mathrm{mmol})$, and $(\mathrm{U})-{ }^{14} \mathrm{C}-\alpha$-D-galactose1-phosphate, potassium salt $(8.2 \mathrm{mCi} / \mathrm{mmol})$ were initially purchased from Rosechem Products (Los Angeles, CA) and later from New England Nuclear Corp (Boston, MA). $1-{ }^{14} \mathrm{C}$-D-glucose $(5 \mathrm{mCi} / \mathrm{mmol}), U D P(U)-{ }^{14} \mathrm{C}$-galactose $(298.5 \mathrm{mCi} / \mathrm{mmol})$ and UDP(U)- ${ }^{14} \mathrm{C}$-glucose $(226.8 \mathrm{mCi} / \mathrm{mmol})$ also were purchased from New England Nuclear.

Low EEO agarose (A-6013, type I), low gelling temperature agarose (A-4018, type VII), UDPGlc, glucose-1-phosphate, glucose-1,6-diphosphate, adenosine-5'-triphosphate, Triton X-100, UTP, cysteine, galactose-1-phosphate and UDPGlc dehydrogenase were obtained from Sigma Chemical Co. (St. Louis, MO). NAD, 2(N-morpholino) ethane sulfonic acid, sodium salt monohydrate (Mes, Na), and DTT were from Calbiochem (San Diego. CA). G6PD and PGM were from Boehringer/Mannheim (Indianapolis, IN). DE 81 was from Whatman Co. (Clifton, NJ). Spectrafluor PPO/POPOP concentrate was from Amersham (Arlington Heights, IL). Beta Blend was from West Chem Products (San Diego, CA).

Ovarian tissue was obtained from a 21-y-old galactosemic patient with incipient ovarian failure during laparoscopy and from 14 nongalactosemic adults, between 21 and 72 y of age, undergoing total abdominal hysterectomy and bilateral salpingoophorectomy for uterine disease, breast cancer, and unilateral ovarian cancer, in which case, based on histology, the nonpathologic ovary was used. Nine patients were premenopausal with normal ovarian function, and five were postmenopausal. One postmenopausal woman was receiving estrogen-progestin therapy at the time of oophorectomy. The postmenopausal tissue was, as expected, fibrotic and relatively devoid of follicles.

Testicular tissue was obtained from men undergoing gonadec- 
tomy for prostatic or testicular cancer, in which case the nonpathologic gonad was studied. Informed consents were obtained before surgery. Tissues, once removed, were placed immediately in cold Krebs-Ringer bicarbonate glucose (KRB-glucose, 100 $\mathrm{mg} / 100 \mathrm{ml}$ ) buffer, $\mathrm{pH} 7.4$, before biochemical analysis.

Incubation studies. Ovarian tissue slices were prepared by hand, using sections of potato for grips. Each slice weighed approximately $1 \mathrm{mg}$. The slices were washed in KRB-glucose $(100 \mathrm{mg} / 100 \mathrm{ml})$ buffer, $\mathrm{pH} 7.4$ several times to free away any contaminated potato. Slices were incubated with either $1 \mu \mathrm{Ci}$ of galactose or $1 \mu \mathrm{Ci}$ of glucose in counting vials as previously described (6). At the end of $2 \mathrm{~h}$ of incubation, labeled $\mathrm{CO}_{2}$ was liberated upon addition of acid, collected, and counted. The incubation mixture was subsequently treated with $10 \%$ TCA. The TCA-soluble and TCA-insoluble fractions were separated. The TCA-insoluble fraction was then extracted with chloroformmethanol mixture (3:1) for glycolipids, and the radioactivity was counted. The TCA in the TCA-soluble fraction was removed with ether, and the aqueous fraction was chromatographed on a Dowex-1-formate column eluted with an ammonium formate gradient (7).

Preparation of tissue homogenate for enzyme studies. Tissue samples of $200-400 \mathrm{mg}$ were blotted with tissue paper and homogenized in $1.0 \mathrm{ml}$ of a solution composed of 1 part of 0.1 M DTT, 2 parts of $1.0 \mathrm{M}$ glycine buffer, $\mathrm{pH} 8.7$, and 7 parts of water in a tissue homogenizer (Kontes Co., Vineland, NJ) in an ice water bath for $5 \mathrm{~min}$. The preparation was then centrifuged at $12,000 \times g$ for $15 \mathrm{~min}$ at $4^{\circ} \mathrm{C}$, and the supernatant was used for enzyme assays and protein determinations.

Enzyme assays. All enzyme activities were expressed in terms of products formed, $\mu \mathrm{mol} / \mathrm{h} / \mathrm{g}$ protein. Each enzyme assay has been standardized for linearity in the rate of product formation and concentrations of protein used.

I) Galactokinase activity was determined by a modification of the method of $\mathrm{Ng}$ et al. (8). The incubation mixture contained Tris buffer ( $\mathrm{pH} 7.0$ ), $100 \mathrm{mM} ; \mathrm{MgSO}_{4}, 40 \mathrm{mM}$; NaF, $5 \mathrm{mM}$; ATP, $4 \mathrm{mM} ;{ }^{14} \mathrm{C}$-galactose, $0.555 \mathrm{mM}$ and $50 \mu \mathrm{l}$ tissue extract in a total volume of $100 \mu \mathrm{l}$. The other steps of the procedure for DE 81 paper chromatographic separation and determination of radioactivity are the same as described.

2) Galactose-1-phosphate uridyl transferase (transferase) activity was quantitated by a modification method of $\mathrm{Ng}$ et al. (9). The reaction mixture contained glycine buffer $\mathrm{pH} 8.7,100 \mathrm{mM}$; ${ }^{14} \mathrm{C}-\mathrm{Gal}-1-\mathrm{P}, 1.6 \mathrm{mM}$; UDPGlc, $0.8 \mathrm{mM}$ and $50 \mu \mathrm{l}$ tissue extract in a total volume of $100 \mu \mathrm{l}$. After $30 \mathrm{~min}$ of incubation at $37^{\circ} \mathrm{C}$, $10 \mu \mathrm{l}$ were spotted on DE 81 paper for chromatographic separation. Transferase was also analyzed by agarose gel electrophoresis (10).

3) UDPGal-4-epimerase activity was assayed by measuring the amounts of UDPGlc formed from UDPGal in a Pye-Unicam spectrophotometer. UDPGlc was determined by coupling to NAD reduction with UDPGlc dehydrogenase and measurement of $\mathrm{OD}$ increase at $340 \mathrm{~nm}$. The reaction mixture (total vol, 0.8 $\mathrm{ml}$ ) contained glycine buffer ( $\mathrm{pH} 8.7$ ), $375 \mathrm{mM}$; NAD, $12.5 \mathrm{mM}$; cysteine, $7.5 \mathrm{mM}$ (freshly prepared); UDPGal, $0.66 \mathrm{mM}$, UDPGlc dehydrogenase, $0.602 \mathrm{U}$; and $20 \mu \mathrm{l}$ tissue supernate (150-300 $\mu \mathrm{g}$ protein). Water was used to substitute for UDPGal in the blank.

4) UDPG pyrophosphorylase activity was determined by measuring the amounts of UDPGlc formed from glucose-1phosphate in the presence of UTP in a Pye-Unicam spectrophotometer. The amount of UDPGlc formed was measured in the presence of UDPGlc dehydrogenase as reflected by OD increase at $340 \mathrm{~nm}$. The reaction mixture (total vol $0.815 \mathrm{ml}$ ) contained Tris buffer ( $\mathrm{pH} 8.0), 368 \mathrm{mM}$; NAD, $1.15 \mathrm{mM} ; \mathrm{MgCl}_{2}, 6.14$ mM; UTP, $0.49 \mathrm{mM}$; glucose-1-phosphate, $1.23 \mathrm{mM}$; UDPGlc dehydrogenase, $0.602 \mathrm{U}$, and tissue extract, $5 \mu \mathrm{l}(35-70 \mu \mathrm{g}$ protein). The blank was made using water to replace substrates (UTP and glucose-1-phosphate).

5) UDPGal pyrophorphorylase activity was assayed by a ra- dioactive method similar to transferase except that UTP was used intead of UDPGlc and $\mathrm{MgCl}_{2}(6.14 \mathrm{mM})$ was also added.

6) UDPGal pyrophosphatase activity was assayed by measuring the amount of labeled galactose-1-phosphate formed from UDPGal during incubation (11). The incubation mixture (total vol, $50 \mu \mathrm{l}$ ) contained 2 (N-morpholino) ethane sulfonic acid buffer, pH 6.8, $123 \mathrm{mM}$; Triton X-100, 0.05\%, UDP $\left({ }^{14} \mathrm{C}\right) \mathrm{Gal}$, $0.14 \mathrm{mM}$, and $20 \mu \mathrm{l}$ tissue supernate (about $200 \mu \mathrm{g}$ protein). At the end of $15 \mathrm{~min}$ at $37^{\circ} \mathrm{C}$, the reaction was stopped by adding $25 \mu \mathrm{l}$ of ethanol containing $5 \%$ acetic acid. After centrifugation $(1000 \times g$, for $3 \mathrm{~min}), 25 \mu \mathrm{l}$ of supernate was spotted on DE 81 paper and chromatographed as for transferase, UDPGal, galactose-1-phosphate and galactose were separated. The amount of UDPGal hydrolyzed is based on the sum of galactose-1-phosphate, and galactose produced as tissue also contains hexose phosphatase converting galactose-1-phosphate to galactose.

7) UDPGlc pyrophosphatase activity was assayed by using an incubation mixture containing Tris buffer $(\mathrm{pH} 8.0), 400 \mathrm{mM}$; ${ }^{14} \mathrm{C}$-UDPGlc, $0.14 \mathrm{mM}$; Triton $\mathrm{X}-100,0.05 \%$ and $20 \mu \mathrm{l}$ tissue extract (about 150-200 $\mu \mathrm{g}$ protein) in a total volume of $50 \mu \mathrm{l}$. At the end of $30 \mathrm{~min}$ of incubation, the reaction was stopped by heating at $100^{\circ} \mathrm{C}$ for $2 \mathrm{~min}$. After centrifugation $(10,000 \times g, 3$ $\min ), 20 \mu \mathrm{l}$ of supernate was spotted on DE 81 paper. The chromatographic procedure and calculation for activity are similar to that of UDPGal pyrophosphatase.

Protein concentration was determined by the method of Lowry et al. (12) with BSA as standard. UDPGlc and UDPGal levels were determined by modified methods of Fujimura et al. (13).

\section{RESULTS}

Table 1 compares the results of ${ }^{14} \mathrm{CO}_{2}$ production and of the incorporation of carbon label into TCA-insoluble material from labeled galactose and glucose in the ovarian tissue slices from the galactosemic patient and nongalactosemic controls. With galactose as the substrate, no labeled $\mathrm{CO}_{2}$ was produced by the tissue from the patient with galactosemia. Production of labeled $\mathrm{CO}_{2}$ from glucose was the same for the galactosemic and nongalactosemic tissue. There was little incorporation of labeled galactose into TCA-insoluble fraction in the galactosemic patient compared to controls; contrarily, incorporation into this fraction from labeled glucose was similar for both the patient and the control group. $\mathrm{CO}_{2}$ produced from labeled galactose was similar for the inner and outer portions of the ovary in the one sample studied (182 versus $199 \mathrm{cpm} / \mathrm{mg} \mathrm{wt} / \mathrm{wt}$ ). These data substantiate a defect in galactose metabolism in the ovarian tissue of the galactosemic patient.

Figure 1 shows the pattern of the labeled intermediates separated on the Dowex-1-formate column after incubation with 1${ }^{14} \mathrm{C}$-galactose. In the normal individual, lactate, galactose-1-phos-

Table $1 .{ }^{14} \mathrm{CO}_{2}$ production and incorporation of carbon label into TCA-insoluble material from galactose and glucose*

\begin{tabular}{|c|c|c|c|c|}
\hline & \multicolumn{2}{|c|}{$\begin{array}{c}{ }^{14} \mathrm{CO}_{2}(\mathrm{cpm} / \mathrm{mg} \\
w \mathrm{wt} / \mathrm{wt})\end{array}$} & \multicolumn{2}{|c|}{$\begin{array}{c}\text { TCA-insoluble } \\
\text { material }(\mathrm{cpm} / \mathrm{mg} \\
\text { wt } / \mathrm{wt})\end{array}$} \\
\hline & Galactose & Glucose & Galactose & Glucose \\
\hline $\begin{array}{l}\text { Nongalactosemic } \\
\text { controls }\end{array}$ & $\begin{array}{l}144 \\
161 \\
196\end{array}$ & 161 & $\begin{array}{r}290 \\
168 \\
128 \\
216 \\
92\end{array}$ & 257 \\
\hline $\begin{array}{l}\text { Galactosemic } \\
\text { patients }\end{array}$ & 0 & 109 & 24 & 280 \\
\hline
\end{tabular}

* A total of $1 \mu \mathrm{Ci}$ of labeled galactose (sp act of $15 \mathrm{mCi} / \mathrm{mmol}$ ) and 1 $\mu \mathrm{Ci}$ of labeled glucose (final sp act of $0.53 \mathrm{mCi} / \mathrm{mmol}$ ) was incubated separately with tissue slices for $2 \mathrm{~h}$. 


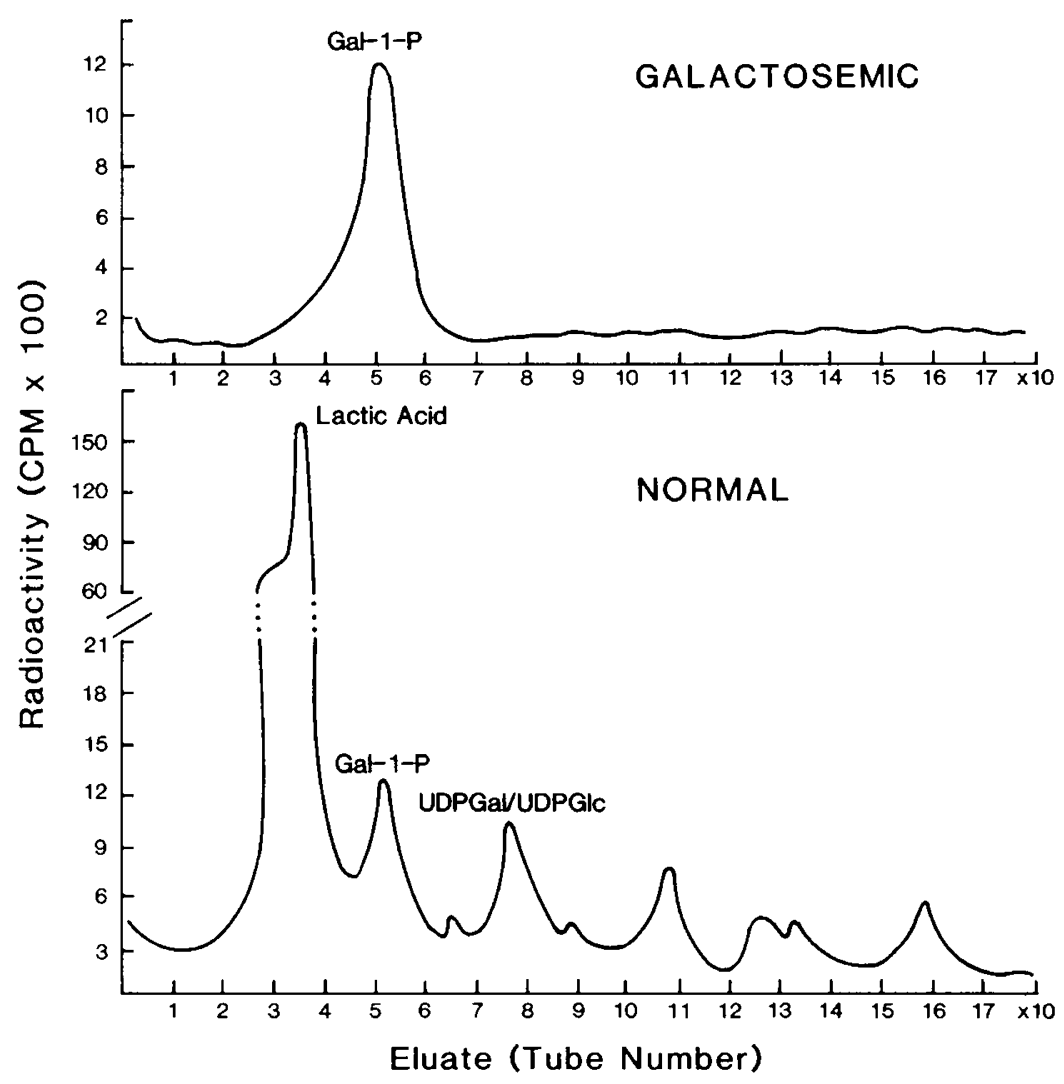

Fig. 1. Dowex-1-formate column chromatograms of ${ }^{14} \mathrm{C}$-labeled intermediates from galactose incubated in ovarian tissue slices.

phate, and UDPhexose, such as UDPGal as well as a number of unidentified peaks were found. In the galactosemic patient, only a single galactose-1-phosphate peak was present. The pattern of labeled intermediates seen in the normal human ovarian tissue is consistent with the Leloir pathway of galactose metabolism.

Table 2 summarizes the activities of enzymes of the galactose pathway found in normal human ovarian tissue. Among them, UDPGlc pyrophosphorylase had the highest sp. act. Epimerase, transferase, galactokinase, UDPGlc pyrophosphatase, and UDPGal pyrophosphatase and UDPGal pyrophosphorylase also exhibited significant activity. There was no difference in enzyme activity between outer and inner portions of the ovary. For transferase, the mean activity was $103 \pm 42(n=13)$ and $85 \pm$ $37(n=5)$, respectively, $(p>0.2)$. Thus, for galactokinase, it was $47 \pm 16$ and $49 \pm 17$. There was no difference in enzyme activity between pre- and postmenopausal ovaries. We did not have enough tissue from the galactosemic patient to perform any enzyme assays.

Table 3 compares the activities of galactokinase, transferase, epimerase, and UDPGlc pyrophosphorylase in normal human ovary, erythrocytes, and testes. The activities of these enzymes are highest in the ovary. For galactokinase, the activity in the ovary is 47 times that of red blood cells and 10 times that of testes. Transferase activity in the ovary is four times that of red blood cells and two times that of testes, whereas UDPGlc pyrophosphorylase is 550 times that of red blood cells and 15 times that of testes. The ratio of galactokinase activity to that of transferase is about 0.5 in the ovary. It is much lower in human erythrocytes and testes, but similar to that reported for liver and kidney (14). The fact that UDPGlc pyrophosphorylase has the highest $\mathrm{sp}$ act in the ovary suggests that nucleotide sugars production may be important in this tissue.

The electrophoretic patterns of transferase from ovarian tissue as compared to other tissues are depicted in Figure 2. The dark lines correspond to the position of fluorescent bands (NADPH) generated by the activity of transferase. Three activity bands
Table 2. Enzyme activities related to metabolism of galactose in human ovarian tissue

\begin{tabular}{lrccc}
\hline & \multicolumn{4}{c}{ Activity* } \\
\cline { 2 - 5 } & $n$ & Mean & SD & Range \\
\hline Galactokinase & 13 & 47 & 17 & $29-83$ \\
Gal-1-P uridyltransferase & 13 & 103 & 42 & $35-190$ \\
UDPGal-4-epimerase & 13 & 231 & 69 & $100-341$ \\
UDPGlc pyrophosphorylase & 13 & 5771 & 1662 & $4028-9900$ \\
UDPGal pyrophosphorylase & 13 & 6.0 & 2.5 & $2.3-10$ \\
UDPGlc pyrophosphatase & 10 & 55 & 23 & $29-98$ \\
UDPGal pyrophosphatase & 9 & 27 & 18 & $0-68$ \\
\hline
\end{tabular}

* Activity is expressed in terms of $\mu \mathrm{mol} / \mathrm{h} / \mathrm{g}$ protein.

Table 3. Comparative activities of enzymes associated with galactose metabolism in human ovaries, erythrocytes, erythrocytes,

UDPGlc pyrophos-

Galactokinase Transferase Epimerase phorylase $\begin{array}{lllll}\text { Ovaries }(n=13) & 47 \pm 17 & 103 \pm 42 & 231 \pm 69 & 5771 \pm 1662\end{array}$ $\begin{array}{lllll}\text { Testes }(n=8) & 4 \pm 2 & 45 \pm 15 & 88 \pm 50 & 883 \pm 733\end{array}$

$\begin{array}{lllll}\text { Erythrocytes } & 1 & 25 & 10 & 10\end{array}$

* Enzyme activities in ovary and testes are expressed in terms of $\mu \mathrm{mol} /$ $\mathrm{h} / \mathrm{g}$ protein and in erythrocytes as $\mu \mathrm{mol} / \mathrm{hr} / \mathrm{g} \mathrm{Hb}$ reported in the literature.

similar to the patterns observed for leukocytes, placenta, and testes were found. This pattern differs from erythrocyte transferase, which usually migrates as a single band, and liver, which exhibits five bands (15). In one ovary, two additional minor 


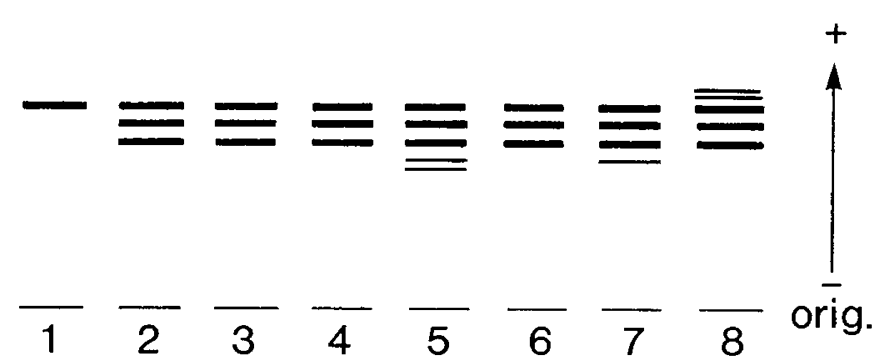

Fig. 2. Electrophoresis of human transferase: 1, erythrocytes; 2, leukocytes; 3, placenta; 4 , testes; 5 , liver; $6-8$, ovaries.

anodal bands were observed, and in another ovary one additional band was observed.

The levels of UDPGlc and UDPGal in the control ovarian tissue are much higher in comparison to the testes: for UDPGlc, 75 versus 31, and for UDPGal, 19 versus $4(\mu \mathrm{mol} / 100 \mathrm{~g}$ wet tissue), respectively.

\section{DISCUSSION}

Figure 3 depicts the pathway of galactose metabolism and the enzymes involved in mammalian tissues. The main pathway described by Leloir and his coworkers consists of three sequential steps catalyzed by galactokinase, transferase, and epimerase, respectively. The products of these reactions are UDPGal and glucose-1-phosphate. In turn, UDPGal, by the action of epimerase, is converted to UDPGlc. Both UDPGlc and UDPGal are essential for glycoprotein and glycolipid synthesis. An important accessory reaction is mediated by UDPGlc pyrophosphorylase. This reaction results in the formation of the nucleotide sugar UDPGlc from UTP and glucose-1-phosphate. The other reactions involving UDPGal pyrophosphorylase and UDPGlc and UDPGal pyrophosphatases are of unknown importance. Galactitol and galactonate accumulate when galactose concentration in tissue is sufficiently elevated due to reactions catalyzed by aldose reductase and galactose dehydrogenase, respectively.

In the present study, the enzymes known to be involved with galactose metabolism were present in human ovarian tissue. UDPGlc pyrophosphorylase has the highest activity among all enzymes determined, suggesting that nucleotide sugar production may be important in normal ovarian tissue, perhaps playing a critical role in support of germ cells, maturation of follicles and/ or steroidogenesis. It is likely that UDPGIc and UDPGal pyrophosphorylase activities are carried out by the same protein with lesser activity toward the latter (16). Active metabolism of galactose in normal ovarian tissue also was demonstrated by isolation of labeled intermediates. Chick oviduct contains abundant galactose-containing substances including uridine sugars, suggesting the importance of galactose metabolism in this tissue (17). It is of interest that comparative enzyme activities in the testes are much lower as compared to the ovary (Table 3 ). We have also found that nucleotide sugar concentrations such as UDPGlc and UDPGal are much higher in ovary than testes of nongalactosemics, suggesting active synthesis of glycoproteins, glycolipids, and other galactose-containing macromolecules. It may be that the abnormal gonadal function in galactosemic females and the normal gonadal function found in males are related to the differences in galactose metabolism noted in these organs.

In the ovarian tissue obtained from a galactosemic female, the enzyme block in the transferase step was further demonstrated by the accumulation of galactose-1-phosphate. There was no $\mathrm{CO}_{2}$ production from labeled galactose, and there was little incorporation of labeled galactose into TCA-insoluble material. This was in marked contrast to the findings obtained in samples from nongalactosemic patients.

Although dietary treatments results in a marked decrease in tissue galactose-1-phosphate, premature ovarian failure occurs in

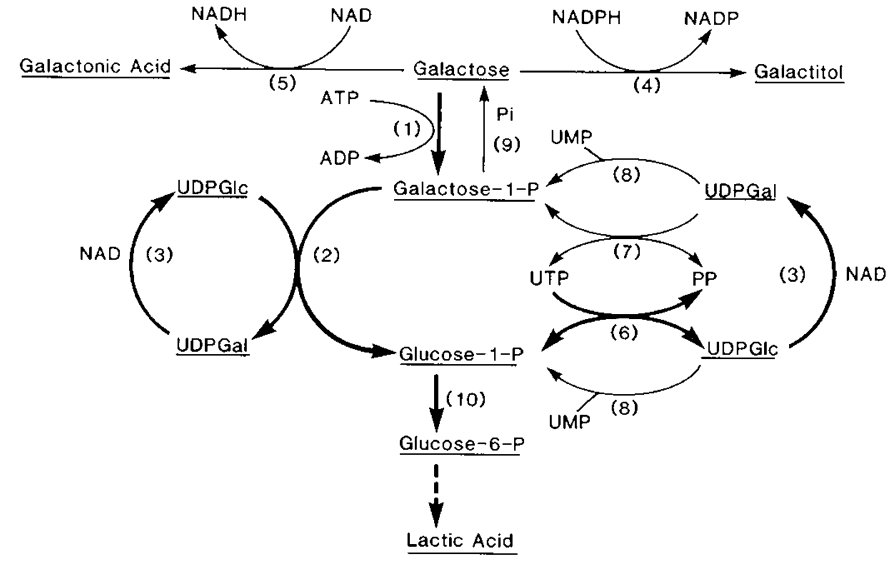

Fig. 3. Metabolic pathways of galactose. 1 , galactokinase; 2 , transferase; 3 , epimerase; 4 , aldose reductase; 5 , galactose dehydrogenase; 6 , UDPGIc pyrophosphorylase; 7, UDPGal pyrophosphorylase; 8, UDPhexose pyrophosphatase(s); 9, phosphatase(s); 10, phosphoglucomutase.

treated patients. This suggests that galactose-1-phosphate toxicity may not be the sole causative factor leading to ovarian failure. An abnormality in nucleotide sugar metabolism may be involved in the pathogenesis of the ovarian failure. One possible mechanism would be the effect of abnormal nucleotide sugar pool size in the synthesis of glycoconjugates. A decrease in synthesis of galactoproteins and galactolipids could result from a decreased UDPGal concentration due to the transferase defect. Consistent with this hypothesis has been our observation of a decrease in UDPGal concentration in erythrocytes, cultured skin fibroblasts, and liver tissue of galactosemic patients (18). A similar deficit in the ovary could explain the hypergonadotropic hypogonadism seen in patients with this inborn error of metabolism. Furthermore, patients with low transferase activity who have normal levels of UDPGal continue to exhibit normal ovarian function (19).

Acknowledgment. The authors thank Mrs. Lee Mollison for the preparation of this manuscript.

\section{REFERENCES}

1. Kaufman FR, Kogut MD, Donnell GN, Gobelsmann U, March C, Koch R 1981 Hypergonadotrophic hypogonadism in female patients with galactosemia. N Engl J Med 304:994-998

2. Hoefnagel D, Wurster-Hill D, Child EL 1979 Ovarian failure in galactosemia. Lancet 2:1197

3. Morrow RJ, Atkinson AB, Corson OJ, Corson NAJ, Sloan JM, Traub AL 1985 Ovarian failure in a young woman with galactosemia. Ulster Med J $54: 218-220$

4. Chen YT, Mattison DR, Feigenbaum L, Fukui H, Schulman JD 1981 Reduction in oocyte number following prenatal exposure to a diet high in galatose. Science 214:1145-1147

5. Xu YK, Ng WG, Kaufman FR, Lobo R, Donnell GN 1987 Galactose metabolism in human ovary. Clin Res 35:213 (abstr)

6. Blaskovics ME, Ng WG, Donnell GN 1978 Prenatal diagnosis and a case report of isovaleric acdemia. J Inherited Metab Dis 1:9-11

7. Ng WG, Bergren WR, Donnell GN 1964 Galactose-1-phosphate uridyl transfease activity in galactosemia. Nature 203:845-847

8. Ng WG, Donnell GN, Bergren WR 1965 Galactokinase activity in human erythrocyte. J Lab Clin Med 66:115-121

9. Ng WG, Bergren WR, Donnell GN 1967 An improved procedure for the assay of hemolysate galactose-1-phosphate uridyl transferase activity by the use of ${ }^{14} \mathrm{C}$-labeled galactose-1-phosphate. Clin Chim Acta 15:489-492

10. Lee JES, Ng WG 1980 Semi-micro techniques for the genotyping of galactokinase and galactose-1-phosphate uridyl transferase. Clin Chim Acta 124:351-356

11. Jato-Rodriguez JJ, Nelson JD, Mookerjea S 1976 Effect of estrodial and progesterone on UDPgalactose pyrophosphatase activity in the endometrium of ovariectomized rats. Biochim Biophys Acta 428:639-646

12. Lowry OH, Rosebrough NJ, Farr AL, Rondall RJ 1951 Protein measurement with the Folin phenol reagent. J Biol Chem 193:265-275 
13. Fujimura Y, Kawamura M, Naruse $\mathrm{H} 1983$ A new mass screening method for determining UDP galactose in blood. Tokohu J Exp Med 141:263-268

14. Shin-Buehring YS, Beier T, Tan A, Osang M, Schaub J 1977 The activity of galactose-1-phosphate uridyltransferase and galactokinase in human fetal organs. Pediatr Res 11:1003-1009

15. Ng WG, Donnell GN, Bergren WR, Alfi O, Golbus MS 1977 Prenatal diagnosis of galactosemia. Clin Chim Acta 74:227-235

16. Ting WK, Hansen RG 1968 Uridine diphosphate galactose pyrophosphorylase from calf liver. Proc Soc Exp Med 127:960-962

17. Suzuki S 1962 A novel uridine nucleotide containing $N$-acetylglucosamine and galactose. J Biol Chem 237:1393-1399

18. Ng WG, Xu YK, Kaufman FR, Donnell GN 1987 Uridine nucleotide sugar deficiency in galactosemia implications. Clin Res 34:212 (abstr)

19. Kaufman FR, Xu YK, Ng WG, Donnell GN 1988 Correlation of ovarian function with galactose- 1 -phosphate uridyl transferase levels in galactosemia. J Pediatr 112:754-756 